\title{
SENSITIVITY OF YEASTS TO 5-FLUOROCYTOSINE
}

\author{
D. C. E. Speller AND M. G. Davies \\ Department of Microbiology, Bristol Royal Infirmary, Bristol BS2 $8 \mathrm{HW}$
}

THE anti-fungal agent, 5-fluorocytosine (5FC), is active in vitro against a limited number of species, but these include Candida sp., Torulopsis glabrata, and Cryptococcus neoformans, and the drug has been used successfully in the treatment of clinical infections by these fungi. The oral route of administration and the relative freedom from toxic effects are advantages of 5FC-in contrast to amphotericin-B, the established treatment for systemic mycosesbut primary resistance to $5 \mathrm{FC}$ in unexposed fungal isolates and resistance arising during treatment with the drug have been reported (Shadomy, 1970). In some series reported in the United States, a very large number of the isolates tested were primarily resistant to 5FC (Shadomy, 1970; Utz, 1972) though this has not been the experience of workers in Great Britain (Dr J. Garrod, personal communication). This report concerns the sensitivity to 5FC of 778 yeasts isolated consecutively in two general hospital laboratories.

\section{MATERIAL AND METHODS}

All yeasts isolated in moderate to heavy growth from specimens received in the Department of Bacteriology of Bristol Royal Infirmary between November 1969 and March 1971 were examined; urinary isolates were included only if the viable particle count was $10^{4}$ per $\mathrm{ml}$ or more. In all, 678 isolates were obtained in this way. Another 100 isolates selected in a similar manner at the Radcliffe Infirmary, Oxford, were also examined. No significant differences in sensitivity between the two groups were observed and they are considered together in this report. No patient had previously been treated with $5 \mathrm{FC}$.

In identification of the isolates, they were first subjected to the serum germ-tube test (Taschdjian, Burchall and Kozinn, 1960). Those giving a negative result were further identified by morphology in corn meal agar and by carbohydrate assimilation and fermentation tests after Lodder (1970). Germ-tube-positive isolates were assumed to be Cand. albicans, unless they were resistant to SFC. Resistant isolates were subjected to further tests to distinguish Cand. albicans from Cand. stellatoidea.

Minimum inhibitory concentrations (MIC) and minimum fungicidal concentrations (MFC) were estimated by the methods of Marks and Eickhoff (1971). Known sensitive and resistant strains of Cand. albicans were included in each experiment. All isolates were subjected to a screening test with 5FC, $1 \mu \mathrm{g}$ per ml, incorporated in Yeast Morphology Agar (Difco), incubated at $37^{\circ} \mathrm{C}$ for $48 \mathrm{hr}$. Isolates giving visible growth at this time were tested for MIC and MFC by the broth dilution method, against doubling dilutions of 5FC from $250 \mu \mathrm{g}$ per $\mathrm{ml}$ to $0.25 \mu \mathrm{g}$ per $\mathrm{ml}$ in Yeast Nitrogen Base (Difco) with the addition of dextrose and asparagine (Shadomy, 1969), with a final inoculum of approx. $10^{4}$ viable particles per $\mathrm{ml}$ and incubation for $48 \mathrm{hr}$ at $37^{\circ} \mathrm{C}$. The highest dilution at which there was no visible growth was taken as the MIC; $0.005-\mathrm{ml}$ amounts from each dilution were subcultured on to dextrose peptone agar and incubated for $48 \mathrm{hr}$, and the highest dilution yielding no growth, or less than four colonies, was taken as the MFC. The MIC was also estimated for 100 isolates randomly selected from those that gave no growth at $48 \mathrm{hr}$ in the screening test.

Received 16 Oct. 1972; accepted 21 Dec. 1972.

J. MED. MICROBIOL,-VOL. 6 (1973) 


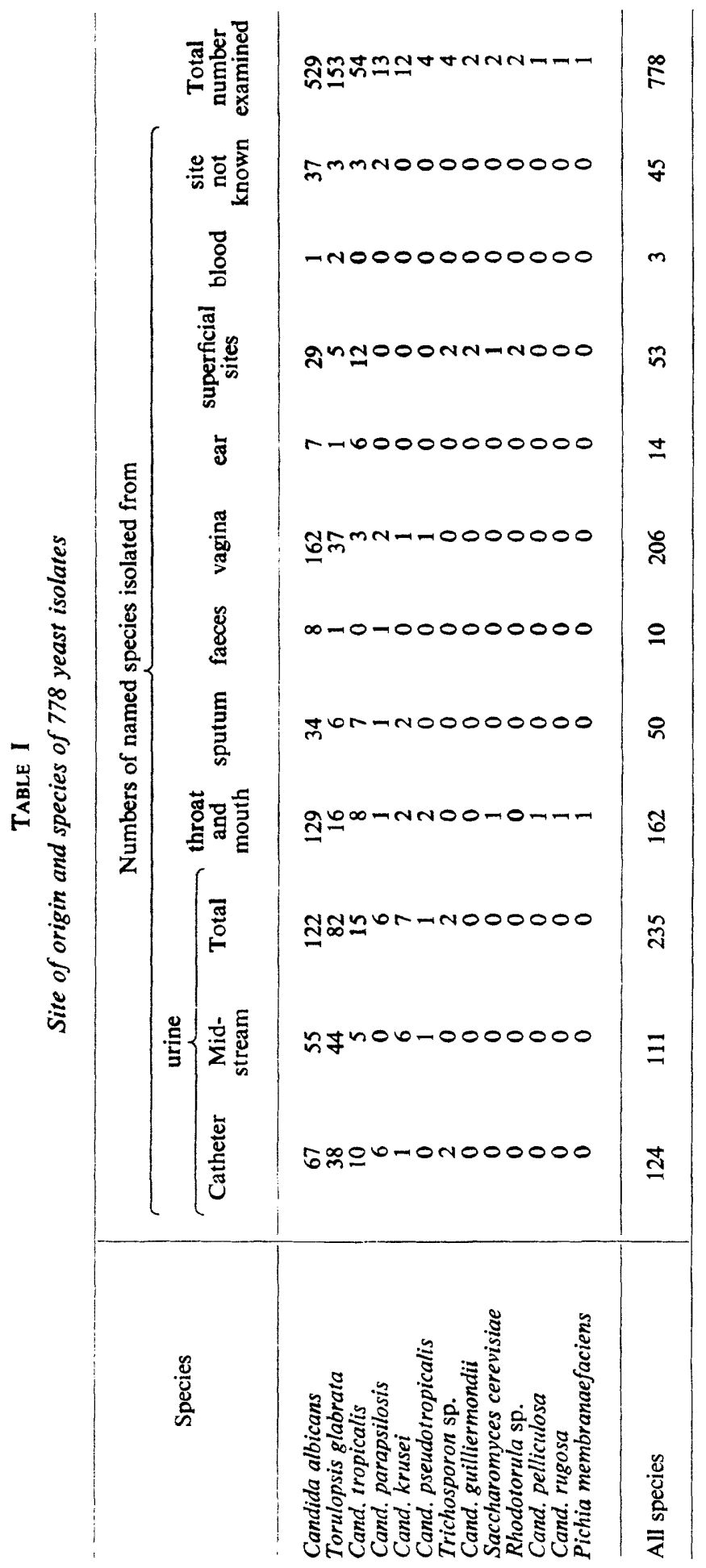




\section{RESULTS}

The sites of origin of the isolates and their species are given in table I. The observed MIC values and the percentage of the isolates that were resistant

\section{TABLE II}

Minimum inhibitory concentrations of $5 F C$ for 778 yeast isolates

\begin{tabular}{|c|c|c|c|c|c|c|c|c|c|c|c|c|c|}
\hline \multirow{2}{*}{ Species } & \multicolumn{11}{|c|}{$\begin{array}{l}\text { Numbers of named species inhibited by concentrations } \\
(\mu \mathrm{g} \text { per ml) of 5FC of }\end{array}$} & \multirow{2}{*}{$\begin{array}{c}\text { Total } \\
\text { number } \\
\text { examined }\end{array}$} & \multirow{2}{*}{$\begin{array}{l}\text { Percentage } \\
\text { resistant }\end{array}$} \\
\hline & $>250$ & 250 & 125 & $62 \cdot 5$ & 31 & 16 & 8 & 4 & 2 & 1 & $<1$ & & \\
\hline $\begin{array}{l}\text { Cand. albicans } \\
\text { T. glabrata } \\
\text { Cand. tropicalis } \\
\text { Cand. parapsilosis } \\
\text { Cand. krusei } \\
\text { Trichosporon sp. } \\
\text { Cand. rugosa } \\
\text { P. membranaefaciens }\end{array}$ & $\begin{array}{r}20 \\
0 \\
0 \\
0 \\
1 \\
0 \\
0 \\
0\end{array}$ & $\begin{array}{l}0 \\
0 \\
2 \\
0 \\
0 \\
1 \\
0 \\
0\end{array}$ & $\begin{array}{l}2 \\
0 \\
0 \\
1 \\
0 \\
0 \\
0 \\
0\end{array}$ & $\begin{array}{l}2 \\
0 \\
1 \\
0 \\
0 \\
1 \\
0 \\
0\end{array}$ & $\begin{array}{l}0 \\
1 \\
0 \\
0 \\
0 \\
0 \\
0 \\
0\end{array}$ & $\begin{array}{l}2 \\
0 \\
0 \\
0 \\
1 \\
1 \\
1 \\
0\end{array}$ & $\begin{array}{l}1 \\
0 \\
0 \\
0 \\
2 \\
1 \\
0 \\
0\end{array}$ & $\begin{array}{l}1 \\
0 \\
0 \\
0 \\
0 \\
0 \\
0 \\
1\end{array}$ & $\begin{array}{l}7 \\
0 \\
2 \\
0 \\
2 \\
0 \\
0 \\
0\end{array}$ & $\begin{array}{l}3 \\
1 \\
1 \\
0 \\
0 \\
0 \\
0 \\
0\end{array}$ & $\begin{array}{r}491 \\
151 \\
48 \\
12 \\
6 \\
0 \\
0 \\
0\end{array}$ & $\begin{array}{r}529 \\
153 \\
54 \\
13 \\
12 \\
4 \\
1 \\
1\end{array}$ & $\begin{array}{c}4 \cdot 5 \\
0 \cdot 7 \\
5 \cdot 6 \\
7 \cdot 7 \\
8 \cdot 3 \\
50 \\
0 \\
0\end{array}$ \\
\hline $\begin{array}{l}\text { Cand. pseudotropicalis } \\
\text { Cand. guilliermondii } \\
\text { S. cerevisiae } \\
\text { Rhodotorula sp. } \\
\text { Cand. pelliculosa }\end{array}$ & 0 & 0 & 0 & 0 & 0 & 0 & 0 & 0 & 0 & 0 & 11 & 11 & 0 \\
\hline All species & 21 & 3 & 3 & 4 & 1 & 5 & 4 & 2 & 11 & 5 & 719 & 778 & $4 \cdot 1$ \\
\hline
\end{tabular}

* MIC $\geqq 31 \mu \mathrm{g} 5 \mathrm{FC}$ per $\mathrm{ml}$.

TABLE III

Minimum fungicidal concentrations of 5FC for 66 isolates that gave growth on plates containing $1 \mu \mathrm{g}$ antibiotic per $\mathrm{ml}$

\begin{tabular}{|c|c|c|c|c|c|c|c|c|c|c|c|}
\hline \multirow{2}{*}{ Species } & \multicolumn{10}{|c|}{$\begin{array}{l}\text { Numbers of named species killed by concentrations ( } \mu \mathrm{g} \text { per } \mathrm{ml}) \\
\text { of } 5 \mathrm{FC} \text { of }\end{array}$} & \multirow{2}{*}{$\begin{array}{c}\text { Total } \\
\text { number } \\
\text { examined }\end{array}$} \\
\hline & $>250$ & 250 & 125 & 62.5 & 31 & 16 & 8 & 4 & 2 & 1 & \\
\hline $\begin{array}{l}\text { Cond. albicans } \\
\text { T. glabrata } \\
\text { Cand. tropicalis } \\
\text { Cand. parapsilosis } \\
\text { Cand. krusei } \\
\text { Trichosporon sp. } \\
\text { Cand. rugosa } \\
\text { P. membranaefaciens }\end{array}$ & $\begin{array}{r}35 \\
1 \\
5 \\
1 \\
1 \\
2 \\
0 \\
0\end{array}$ & $\begin{array}{l}0 \\
0 \\
0 \\
0 \\
0 \\
2 \\
0 \\
0\end{array}$ & $\begin{array}{l}2 \\
0 \\
1 \\
0 \\
0 \\
0 \\
0 \\
0\end{array}$ & $\begin{array}{l}2 \\
0 \\
0 \\
0 \\
1 \\
0 \\
1 \\
0\end{array}$ & $\begin{array}{l}1 \\
0 \\
0 \\
0 \\
1 \\
0 \\
0 \\
0\end{array}$ & $\begin{array}{l}1 \\
0 \\
0 \\
0 \\
2 \\
0 \\
0 \\
0\end{array}$ & $\begin{array}{l}1 \\
0 \\
0 \\
0 \\
0 \\
0 \\
0 \\
0\end{array}$ & $\begin{array}{l}1 \\
1 \\
1 \\
0 \\
0 \\
0 \\
0 \\
1\end{array}$ & $\begin{array}{l}1 \\
0 \\
0 \\
0 \\
1 \\
0 \\
0 \\
0\end{array}$ & $\begin{array}{l}0 \\
0 \\
0 \\
0 \\
0 \\
0 \\
0 \\
0\end{array}$ & $\begin{array}{r}44 \\
2 \\
7 \\
1 \\
6 \\
4 \\
1 \\
1\end{array}$ \\
\hline All species & 45 & 2 & 3 & 4 & 2 & 3 & 1 & 4 & 2 & 0 & 66 \\
\hline
\end{tabular}

to $5 \mathrm{FC}$ (MIC $31 \mu \mathrm{g}$ per $\mathrm{ml}$ or more) are given in table II, and the MFC of the isolates that grew on plates containing $1 \mu \mathrm{g}$ of $5 \mathrm{FC}$ per $\mathrm{ml}-$ but excluding five 
strains that gave scanty growth and proved to have a MIC and a MFC below $1 \mu \mathrm{g}$ per $\mathrm{ml}$-in table III. Table IV shows the MIC values of 100 isolates that failed to grow on plates containing $1 \mu \mathrm{g}$ of $5 \mathrm{FC}$ per $\mathrm{ml}$; it will be seen that none had an MIC in broth exceeding $1 \mu \mathrm{g}$ per $\mathrm{ml}$. All such isolates have therefore been included in table II as having an MIC of less than $1 \mu \mathrm{g}$ per $\mathrm{ml}$.

No significant differences were found in the percentages of resistant isolates among those from different types of specimen.

TABLE IV

Minimum inhibitory concentration of SFC for 100 isolates that gave no growth on plates containing $1 \mu \mathrm{g}$ antibiotic per $\mathrm{ml}$

\begin{tabular}{cccccccccc}
\hline \multicolumn{8}{c}{ Number of isolates inhibited by concentrations $(\mu \mathrm{g}$ per $\mathrm{ml})$ of $5 \mathrm{FC}$ of } \\
\hline & 1 & 0.5 & 0.25 & 0.125 & 0.06 & 0.03 & 0.01 & $<0.01$ \\
\hline 0 & 0 & 3 & 8 & 36 & 36 & 14 & 3 & 0 \\
\hline
\end{tabular}

\section{Discussion}

We examined all yeasts isolated in moderate or heavy growth, but do not suggest that all or even most of them were exercising a pathogenic role in the patients. In many cases, yeasts were not being sought specifically, but had been found in the course of a bacteriological examination. Again, the yeasts isolated will have been selected by the incubation temperature of $37^{\circ} \mathrm{C}$ used for almost all specimens and by the short incubation times of 20 to $40 \mathrm{hr}$.

Most of the species found, however, may be pathogenic on occasion, and, because infection is usually endogenous, yeasts colonising body sites are likely to be the invaders when general or local defences are impaired. Ability to grow at $37^{\circ} \mathrm{C}$ is a requirement for systemic infection. The opportunistic pathogenicity of Cand. albicans is undoubted, and Tor. glabrata is being reported more frequently in a pathogenic role (Marks et al., 1970). The other species of Candida and Rhodotorula have been described in systemic infection (Richart and Dammin, 1960; Louria et al., 1967), though infection with Rhodotorula may well resolve without treatment when the source of infection-usually an intravenous infusion-is removed. Trichosporon spp. have rarely been reported in deep infection (Steer et al., 1972) but were found in the present series repeatedly in heavy growth from the catheter urine in two patients, though admittedly only for a limited period.

Very small variations in the inoculum and the medium used may affect the results of determinations of 5FC sensitivity (Scholer, 1970). Apparent differences in sensitivity between species may result from factors other than intrinsic resistance, for instance the mode of growth and the production of mycelium. We found, as did Marks and Eickhoff (1971), that the incorporationplate technique is reliable for detecting yeasts with a high MIC in liquid medium, which formed at the least a few colonies on a plate containing $1 \mu \mathrm{g}$ of $5 \mathrm{FC}$ per $\mathrm{ml}$ after $48 \mathrm{hr}$. 
The great difference between the MIC and the MFC can be seen by comparison of tables II and III. The antibiotic is only slowly fungicidal in synthetic media in vitro (Scholer, 1970), and a longer incubation time than the $40 \mathrm{hr}$ used by us and most others would give a MFC nearer to the MIC. Even some isolates with a very low MIC $(0.03-0.06 \mu \mathrm{g}$ per ml) showed persistence of small numbers of viable organisms after exposure to high concentrations of 5FC. Usually the MIC of these survivors was the same as that of the original strain, but occasionally we observed the selection of highly resistant organisms, remarked upon by Holt and Newman (1972). Because these may be very important in the development of resistance during treatment, careful testing in liquid medium, with a long incubation period and subculture, should be carried out when long-term treatment with 5FC is contemplated.

Serum concentrations of $10-40 \mu \mathrm{g}$ of $5 \mathrm{FC}$ per ml may be achieved for $6-10$ $\mathrm{hr}$ after a 2-g dose (Utz, 1972). In analysing our results and comparing them with those of other authors who used similar methods we have considered isolates with a MIC of $16 \mu \mathrm{g}$ per $\mathrm{ml}$ or less to be sensitive to 5FC, and those with a MIC of $31 \mu \mathrm{g}$ per $\mathrm{ml}$ or more to be resistant. Our series contained only 4.1 per cent. of resistant isolates, a much lower proportion than has been reported by others. In the series of yeasts described by Marks and Eickhoff, approximately 25 per cent. had MIC values of $31 \mu \mathrm{g}$ per $\mathrm{ml}$ or more, as did at least 67 per cent. of Shadomy's (1970) series of Candida spp. Cand. albicans was the predominating species in our series and 4.5 per cent. of the 529 isolates were resistant. Steer et al. found two of 25 Cand. albicans isolates to be resistant, and Shadomy (1970) three of six isolates. We encountered a single resistant Tor. glabrata in 153 isolates, and Marks et al. (1971) appear to have found one or two very resistant isolates among 35 tested. In our study, the proportion of resistant Cand. tropicalis was $5 \cdot 6$ per cent.

It is very difficult to assess the effectiveness of drug treatment in opportunistic infection, when host factors so greatly influence the outcome. There are, however, many reports of successful treatment with $5 \mathrm{FC}$-some after the failure of amphotericin B-in cryptococcal meningitis and pulmonary infection (McGill et al., 1969; Utz et al., 1969), in candida and torulopsis septicaemia and endocarditis (Tassel and Madoff, 1968; Webb et al., 1970; Record et al., 1971; Steer et al.), in urinary-tract infection (Davies and Reeves, 1971; Schönebeck, 1971) and in eye infection (Richards et al., 1969). Many of these authors also report treatment failures with $5 \mathrm{FC}$, often but not always with the development of resistance to this agent. In cryptococcosis, the development of resistance seems to be more likely when smaller doses are used (Shadomy, 1970). Some toxic effects on the bone marrow and liver have been observed (Grunberg et al., 1967; Steer et al.) but these are usually reversible and of little importance compared with those produced by treatment with amphotericin B (Scholer, 1968).

5-Fluorocytosine certainly has a place in the treatment of systemic yeast infections but the development of resistance puts limitations on its use; primary resistance, however, is uncommon. 


\section{SUMMARY}

Amongst 778 yeasts isolated from clinical specimens and tested for sensitivity to 5 -fluorocytosine, 4.1 per cent. had minimum inhibitory concentrations of $31 \mu \mathrm{g}$ of $5 \mathrm{FC}$ per ml, or more, a lower percentage of primary resistance than in some reported series. Resistance was found in 4.5 per cent. of Candida albicans, 0.7 per cent. of Torulopsis glabrata and 5.6 per cent. of Cand. tropicalis. The minimum fungicidal concentrations for the resistant candida isolates greatly exceeded the minimum inhibitory concentrations, and some yeasts with low minimum inhibitory concentrations contained small numbers of highly resistant organisms.

We are indebted to Dr Mary P. English for much advice and assistance in the identification of yeasts, to the Centraalbureau voor Schimmelcultures for the identification of Pichia membranaefaciens, to Mr D. I. Lobban and to the staff of the Bacteriology Department of Bristol Royal Infirmary for supplying yeasts, and to Roche Products, Ltd for 5FC.

\section{REFERENCES}

Davies, R. R., ANd Reeves, D. S. 1971. 5-Fluorocytosine and urinary candidiasis, $B r$. Med. J., 1, 577.

Grunberg, E., Prince, H. N., ANd Utz, J. P. 1967. Observations on the activity of two newer anti-fungal agents, saramycetin $(\mathrm{X}-5079 \mathrm{C})$ and 5-fluorocytosine. Proc. Vth. Internat. Congr. Chemotherapy, Wien, 4, 69.

Holt, R. J., AND NEWMAN, R. L. 1972 . Urinary candidiasis after renal transplantation. Br. Med. J., 2, 714.

LODDER, J. 1970. The yeasts, 2nd ed., Amsterdam and London.

Louria, D. B., Blevins, Anne, Armstrong, D., Burdick, R., ANd Lieberman, P. 1967. Fungemia caused by " nonpathogenic" yeasts. Archs Intern. Med., 119, 247.

MARKS, M. I., AND EICKhoFF, T. C. 1971. Application of four methods to the study of the susceptibility of yeast to 5-fluorocytosine. Antimicrob. Agents Chemother., 1970, p. 491.

Marks, M. I., Langston, Claire, and Eickhoff, T. C. 1970. Torulopsis glabrata-an opportunistic pathogen in man. New Engl. J. Med., 283, 1131.

Marks, M. I., Steer, P., AND EICKhoff, T. C. 1971. In vitro sensitivity of Torulopsis glabrata to amphotericin B, 5-fluorocytosine and clotrimazole (Bay 5097). Appl. Microbiol., 22, 93.

McGill, P. E., Sequira, R., Jindani, A., Nguli, E. T., Forrester, A. T. T., And Fulton, W. F. M. 1969. 5-Fluorocytosine in the treatment of cryptococcal meningitis. E. Afr. Med.J., 46, 663.

Record, C. O., Skinner, J. M., Sleight, P., And Speller, D. C. E. 1971. Candida endocarditis treated with 5-fluorocytosine. Br. Med. J., 1, 262.

Richards, A. B., Jones, B. R., Whitwell, J., and Clayton, Yvonne M. 1969. Corneal and intra-ocular infection by Candida albicans treated with 5-fluorocytosine. Trans. Ophthal. Soc., U.K., 89, 867.

Richart, R., AND Dammin, G. J. 1960. Candida tropicalis as a pathogen for man. New Engl. J. Med., 263, 474.

SCHOLER, H. J., 1968. Chemotherapie von Mykosen der inneren Organe. Schweiz. med. Wschr., 98, 602 .

SChOLeR, H. J. 1970. Antimykoticum 5-fluorocytosin. Mykosen, 13, 179.

SCHÖNEBECK, J. 1971. 5-Fluorocytosine treatment of candidosis of the urinary tract and candida infection localised elsewhere. Proc. Congr. Int. Soc. Human and Animal Mycol., Paris, p. 299. 
Shadomy, S. 1969. In vitro studies with 5-fluorocytosine. Appl. Microbiol., 17, 871.

SнаDомY, S. 1970. Further in vitro studies with 5-fluorocytosine. Infect. Immun., 2, 484.

Steer, P. L., Marks, M. I., Klite, P. D., AND Eickhoff, T. C. 1972. 5-Fluorocytosine: an oral antifungal compound. A report on clinical and laboratory experience. Ann. Intern. Med., 76, 15.

Taschdjan, Claire L., Burchall, J. J., And Kozinn, P. J. 1960. Rapid identification of Candida albicans by filamentation on serum and serum substitutes. J. Dis. Child., 99, 212.

TASSEL, D., AND MAdofF, M. A. 1968. Treatment of candida sepsis and cryptococcus meningitis with 5-fluorocytosine. J. Am. Med. Ass., 206, 830.

Utz, J. P. 1972. Flucytosine. New Engl. J. Med., 286, 777.

Utz, J. P., Tynes, B. S., Shadomy, H. J., Duma, R. J., Kannan, M. M., and Mason, K. N. 1969. 5-Fluorocytosine in human cryptococcosis. Antimicrob. Agents Chemother., 1968 , p. 344.

WebB, A. J., SPELler, D. C. E., AND BuCKLer, K. G. 1970. Torulopsis glabrata septicaemia treated with 5-fluorocytosine. Lancet, 1, 839. 